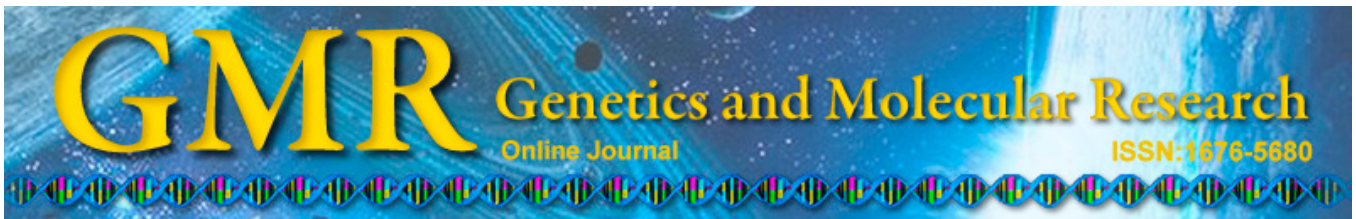

\title{
Rapid discrimination between four seagrass species using hybrid analysis
}

\author{
M. Osathanunkul ${ }^{1}$, P. Madesis ${ }^{2}$, S. Ounjai ${ }^{1}$, C. Suwannapoom ${ }^{3}$ and \\ A. Jampeetong ${ }^{1}$ \\ ${ }^{1}$ Department of Biology, Faculty of Science, Chiang Mai University, \\ Chiang Mai, Thailand \\ ${ }^{2}$ Institute of Applied Biosciences, \\ Centre for Research \& Technology Hellas (CERTH), Thessaloniki, Greece \\ ${ }^{3}$ State Key Laboratory of Genetic Resources and Evolution, \\ Kunming Institute of Zoology, Chinese Academy of Sciences, Kunming, China \\ Corresponding author: M. Osathanunkul \\ E-mail: omaslin@gmail.com
}

Genet. Mol. Res. 14 (2): 3957-3963 (2015)

Received May 26, 2014

Accepted October 27, 2014

Published April 27, 2015

DOI http://dx.doi.org/10.4238/2015.April.27.10

\begin{abstract}
Biological species are traditionally identified based on their morphological features and the correct identification of species is critical in biological studies. However, some plant types, such as seagrass, are taxonomically problematic and difficult to identify. Furthermore, closely related seagrass species, such as Halophila spp, form a taxonomically unresolved complex. Although some seagrass taxa are easy to recognize, most species are difficult to identify without skilled taxonomic or molecular techniques. Barcoding coupled with High Resolution Melting analysis (BAR-HRM) offers a potentially reliable, rapid, and cost-effective method to confirm species. Here, DNA information of two chloroplast loci was used in combination with HRM analysis to discriminate four species of seagrass collected off the southern coast of Thailand. A distinct melting curve presenting one inflection point was generated for each species using $r b c \mathrm{~L}$ primers. While the melting profiles of Cymodocea rotundata and Cymodocea serrulata were not statistically different, analysis of the
\end{abstract}


normalized HRM curves produced with the $r p o C$ primers allowed for their discrimination. The Bar-HRM technique showed promise in discriminating seagrass species and with further adaptations and improvements, could make for an effective and power tool for confirming seagrass species.

Key words: Seagrass; Species identification; DNA Barcoding; HRM analysis; $r b c \mathrm{~L}$; $r p o \mathrm{C}$

\section{INTRODUCTION}

Seagrass is a vital component of marine ecosystems that produces oxygen and provides food and habitat for many aquatic species such as dugongs and green turtles (Orth, 2006; Short et al., 2007). To date, 60 seagrass species have been identified worldwide and of the 12 reported in Thai waters, 11 are found on the Andaman coast and one (Ruppia maritima) on the coast of the Gulf of Thailand (Poovachiranon, 1988; Poovachiranon and Chansang, 1994; Poovachiranon and Adulyanukosol, 1999; Terrados et al., 1999; Hine et al., 2005; Poovachiranon et al., 2006; Sakayaroj et al., 2010). The seagrass of Phuket and Krabi Provinces are of interest to us because of their importance to the native dugongs.

Seagrass reproduces asexually (Reusch et al., 1999) and, with the exception of Enhalus acoroides, sexually by generating flowers and pollinating in the water. Pollinated flowers become fruits and seeds, however, seagrass flowers are short-lived. This feature makes them difficult to observe and collect and thus challenging to accurately identify. In addition, some species such as Halophila spp share a close evolutionary relationship and similar features (Den Hartog and Kuo, 2006). To date, the accurate identification of seagrass species requires the comparison of plant cells to a known specimen by microscopy- and chemical-based techniques. However, these approaches are time-consuming and rely on expensive equipment and technical expertise. Furthermore, a lack in standards pertaining to equipment and species identification results in the high potential for misleading outputs.

To accurately identify seagrass species based on morphological characteristics, the examination of a number of features is required. However, many of these features have a range of phenotypes and can be missing altogether, thus making an accurate identification difficult. One potential method for resolving this issue is by using short orthologous DNA sequences referred to as DNA barcodes (Kress et al., 2005; Hollingsworth et al., 2009). Recently, Lucas et al. (2012) used DNA barcodes to identify seagrass species using single-locus and a combination of multiple loci analyses. Despite recommendations from the Consortium for the Barcode of Life (CBOL Plant Working Group, 2009), the matK and $r b c \mathrm{~L}$ loci were not sufficient to distinguish the samples tested by Lucas et al. (2012). Therefore, a three-locus analysis was performed and Lucas et al. (2012) concluded at the end that the $m a t \mathrm{~K} / r b c \mathrm{~L}$ combination was indeed a straightforward method for the DNA-based identification of seagrass in terms of simplicity and cost-effectiveness.

The aim of this research was to discriminate seagrass species using an approach that combines DNA barcoding with high-resolution melting analysis (BAR-HRM). BARHRM has been shown to offer great potential in several uses related to species identification (Ganopoulos et al., 2012; Faria et al., 2013; Sakaridis et al., 2013) and here we developed this hybrid method to aid in the rapid and accurate identification of seagrass species. Two regions of the chloroplast genome, $r b c \mathrm{~L}$ and $r p o \mathrm{C}$, were used. Importantly, this method can be used in samples that lack the morphological characteristics required for identification. 


\section{MATERIAL AND METHODS}

\section{Sample collection}

Specimens (Cymodocea rotundata, Cymodocea serrulata, Halophila ovalis, and Halodule uninervis) were collected from mixed seagrass beds from Tungkhen Bay, Phuket Province $\left(7^{\circ} 48.539^{\prime} \mathrm{N}, 98^{\circ} 24.692^{\prime} \mathrm{E}\right)$, and Laem Hangnak, Krabi Province $\left(8^{\circ} 01.620^{\prime} \mathrm{N}\right.$, $\left.98^{\circ} 46.420^{\prime} \mathrm{E}\right)$ on the southern coast of Thailand.

\section{Selecting DNA regions}

Several regions of the genome were selected to provide the species molecular data. Previous DNA sequencing analyses of molecular data (Newmaster et al., 2006, 2008; Kress and Erickson, 2007, 2008; Fazekas et al., 2008; Lahaye et al., 2008) suggested that several DNA regions were suitable for barcoding plants and based on these studies, the $r b c \mathrm{~L}$ region was selected for this study. Although the rpoC locus has not yet been used to identify seagrass species, it has been shown to be a candidate barcode for plant identification (Kress and Erickson, 2007) and therefore, was also selected for this study. The seagrass $r b c \mathrm{~L}$ and $r p o \mathrm{C}$ sequences were obtained from GenBank and subjected to rigorous processing to remove the low-quality sequences containing more than $1 \%$ " $\mathrm{N}$ " nucleotides. The processed sequences were aligned using ClustalW and corrected manually. Kimura's two-parameter distances were calculated using MEGA 5 package (Tamura et al., 2011). The distance values were plotted with the Gephi program (Bastian et al., 2009). The processed sequences were used for the HRM primer design.

\section{DNA extractions}

Total genomic DNA was isolated from leaf material using the DNeasy kit (Qiagen). Extracted DNA was stored in sterile microcentifuge tubes at $-20^{\circ} \mathrm{C}$. DNA was amplified in $25 \mu \mathrm{L}$ reaction mixtures containing $1 \mathrm{U}$ Taq Polymerase with $1 \mathrm{X}$ PCR Buffer $(100 \mathrm{mM}$ Tris- $\mathrm{HCl}, \mathrm{pH} 8.3,500 \mathrm{mM} \mathrm{KCl}), 2.5 \mathrm{mM} \mathrm{MgCl}, 0.4 \mathrm{mM}$ dNTPs, $0.5 \mathrm{mM}$ of each primer, and $20 \mathrm{ng} / \mu \mathrm{L}$ template DNA.

\section{HRM analysis}

To determine the characteristic melting temperature $\left(\mathrm{T}_{\mathrm{m}}\right)$ capable of distinguishing the four different seagrass species (C. rotundata, C. serrulata, $H$. ovalis, and H. uninervis), real-time PCR DNA amplification was performed using the $\mathrm{Eco}^{\mathrm{TM}}$ Real-Time PCR system (illumina $^{\circledR}$, San Diego, CA, USA). The $10-\mu \mathrm{L}$ real-time PCR and HRM mixtures contained: $5 \mu \mathrm{L} 2 \mathrm{X}$ THUNDERBIRD ${ }^{\circledR}$ SYBR qPCR Mix, $0.2 \mu \mathrm{M}$ forward (HRM $r b c \mathrm{LF}$ : 5'-TAGACCTTTTTGAAGAAGGTTCTGT-3' and reverse (HRM_rbcLR: 5'-TGAGG̈CGGR CCTTGGAAAGTT-3') primers for $r b c L, 0.2 \mu \mathrm{M}$ forward (HRM_rpoCF: 5'-CCSATTGTATG GGAAATACTT-3') and reverse (HRM_rpoCF: 5'-CTTACAAACTAATGGATGTAA-3') primers for $r p o C$, and $25 \mathrm{ng} 1 \mu \mathrm{L}$ DNA. SYBR fluorescence dye was used to monitor the accumulation of amplified products during PCR. High resolution melting was used to derive the $\mathrm{T}_{\mathrm{m}}$ value. PCR protocol was conducted on a 48 -well plate Helixis using an initial denaturing step at $95^{\circ} \mathrm{C}$ for $5 \mathrm{~min}$ followed by 40 cycles of $95^{\circ} \mathrm{C}$ for $30 \mathrm{~s}, 57^{\circ} \mathrm{C}$ for $30 \mathrm{~s}$, and $72^{\circ} \mathrm{C}$ for 20 
s. The fluorescent data were acquired at the end of each extension step during the PCR cycles. Before HRM, the products were denatured at $95^{\circ} \mathrm{C}$ for $15 \mathrm{~s}$ and then annealed at $50^{\circ} \mathrm{C}$ for 15 $\mathrm{s}$ to form random DNA duplexes. For the HRM experiments, fluorescence data were collected every $0.1^{\circ} \mathrm{C}$ and the $\mathrm{Eco}^{\mathrm{TM}}$ software (version 4.0.7.0) was used to analyze the $\mathrm{T}_{\mathrm{m}}$. The negative derivative of fluorescence $(\mathrm{F})$ over temperature $(\mathrm{T})(\mathrm{dF} / \mathrm{dT})$ curve displays the $\mathrm{T}_{\mathrm{m}}$ while decreasing fluorescence $v_{s}$ increasing temperature is depicted in the normalized raw curve. To generate normalized melt curves and difference melt curves (Wittwer et al., 2003), pre- and post-melt normalization regions were set to define the temperature boundaries of the normalized and difference plots. H. ovalis was set as the reference species.

\section{RESULTS AND DISCUSSION}

Seagrass sequence data obtained from an online database were used to design HRM primers. The distance of all sequences was calculated and then plotted to show how they relate to each other (Figure 1).

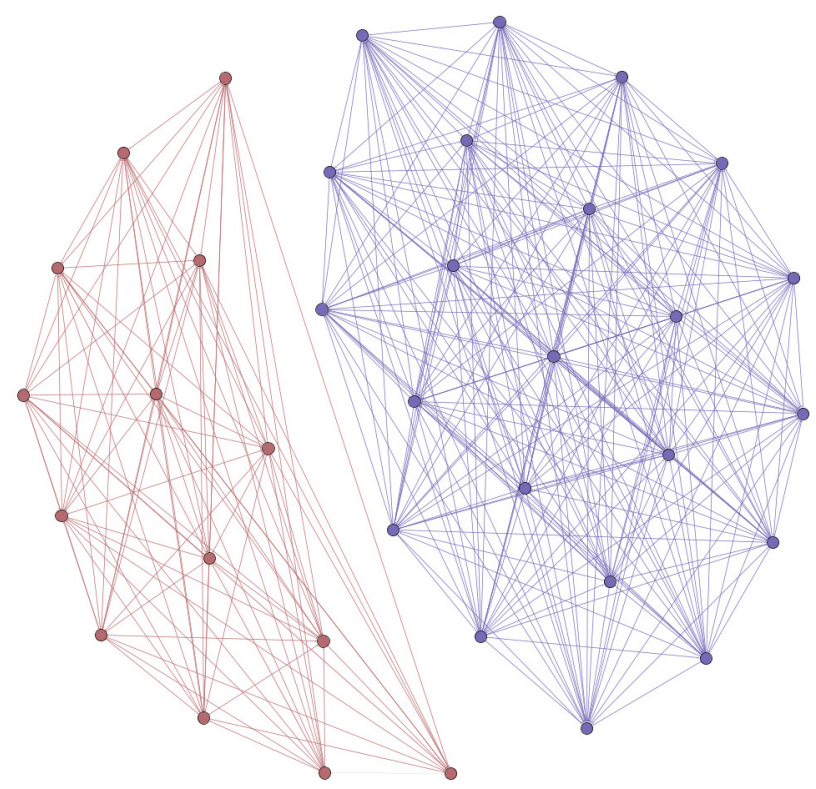

Figure 1. Calculated distance plot of seagrass sequences extracted from GenBank. Pairwise distance calculation was performed by the MEGA 5 program. Purple nodes correspond to $r b c \mathrm{~L}$ sequences and red nodes correspond to rpoC sequences. All edge links refer to related sequences.

All seagrass $r b c \mathrm{~L}$ sequences were grouped together, and in the same way, the $r p o \mathrm{C}$ sequences are also close to each other, as expected. In order to identify and/or discriminate the four seagrass species, two separate HRM were performed, in which the first one using $r b c \mathrm{~L}$ primer pairs and then the rpoC primers were used in the second analysis. The HRM analysis of the $r b c \mathrm{~L}$ barcoding region was evaluated first to identify the four seagrass species. The melting profiles of the $r b c L$ amplicons of four different seagrass species (C. rotundata, C. serrulata, $H$. ovalis, and $H$. uninervis) are represented by peaks. The melting temperature peaks of all 
four seagrass species, obtained from three replicates of HRM performed with $r b c \mathrm{~L}$ primers are presented in Table 1 . The $\mathrm{T}_{\mathrm{m}}$ values are as follows: H. ovalis $81.13^{\circ} \pm 0.06^{\circ} \mathrm{C}$, H. uninervis $80.75^{\circ} \pm 0.17^{\circ} \mathrm{C}$, C. rotundata $79.83^{\circ} \pm 0.06^{\circ} \mathrm{C}$, and C. serrulata $79.90^{\circ} \pm 0.00^{\circ} \mathrm{C}$. Distinct melting curves presenting one inflection point were generated for each species (Figure 2A).

Table 1. $\mathrm{T}_{\mathrm{m}}$ values with standard deviations obtained with the $r b c \mathrm{~L}$ and $r p o \mathrm{C}$ primer pairs for each species.

\begin{tabular}{|c|c|c|}
\hline Species & $r b c \mathrm{LT}_{\mathrm{m}}\left({ }^{\circ} \mathrm{C}\right)$ & $r p o \mathrm{CT}_{\mathrm{m}}\left({ }^{\circ} \mathrm{C}\right)$ \\
\hline Cymodocea rotundata & $79.83 \pm 0.06$ & $79.00 \pm 0.00$ \\
\hline Cymodocea serrulata & $79.90 \pm 0.00$ & $79.53 \pm 0.06$ \\
\hline Halodule uninervis & $80.75 \pm 0.17$ & $79.10 \pm 0.00$ \\
\hline Halophila ovalis & $81.13 \pm 0.06$ & $79.70 \pm 0.00$ \\
\hline
\end{tabular}
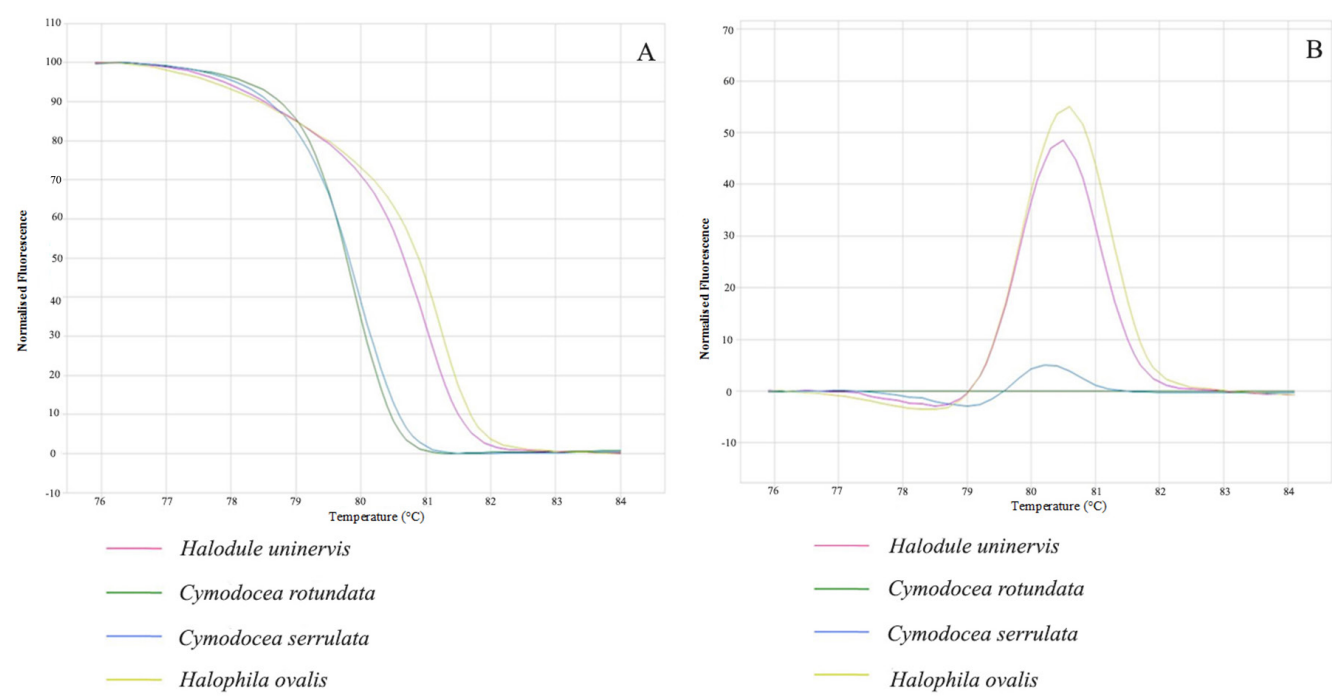

Figure 2. Melting curves obtained by HRM analysis of the $r b c \mathrm{~L}$ specific amplicon when applied to the four seagrass species tested. A. Temperature-shifted melting curves of the $r b c \mathrm{~L}$ amplicons. B. HRM difference plot of the samples amplified by $r b c \mathrm{~L}$ primers.

However, the melting profiles of $C$. rotundata and C. serrulata were not statistically different (data not shown) and thus different specific primers are needed to distinguish these seagrass samples (Figure 2B). Analysis of the normalized HRM curves produced with the rpoC primer allows for the discrimination of C. rotundata and C. serrulata (Figure 3).

The use of HRM combined with the discriminating power of barcoding has been reported recently in the food industry (Ganopoulos et al., 2012; Faria et al., 2013; Sakaridis et al., 2013). Here, we describe the development of the Bar-HRM technique as a rapid, accurate, and economical molecular method to identify seagrass species. Although DNA barcodes alone are sufficient to discriminate species, a more detailed study covering global populations or a high-resolution system is needed for standard setting of seagrass identification (Lucas et al., 2012). The method described here offers great potential in the rapid identification and discrimination of species. The results from this study indicated that the designed primers were 
inadequate, however, by modifying the primers and the primer design methods, the efficiency of this technique will be greatly improved. Furthermore, analysis of DNA sequences from more species, together with additional markers could yield suitable primers with better discriminatory power.

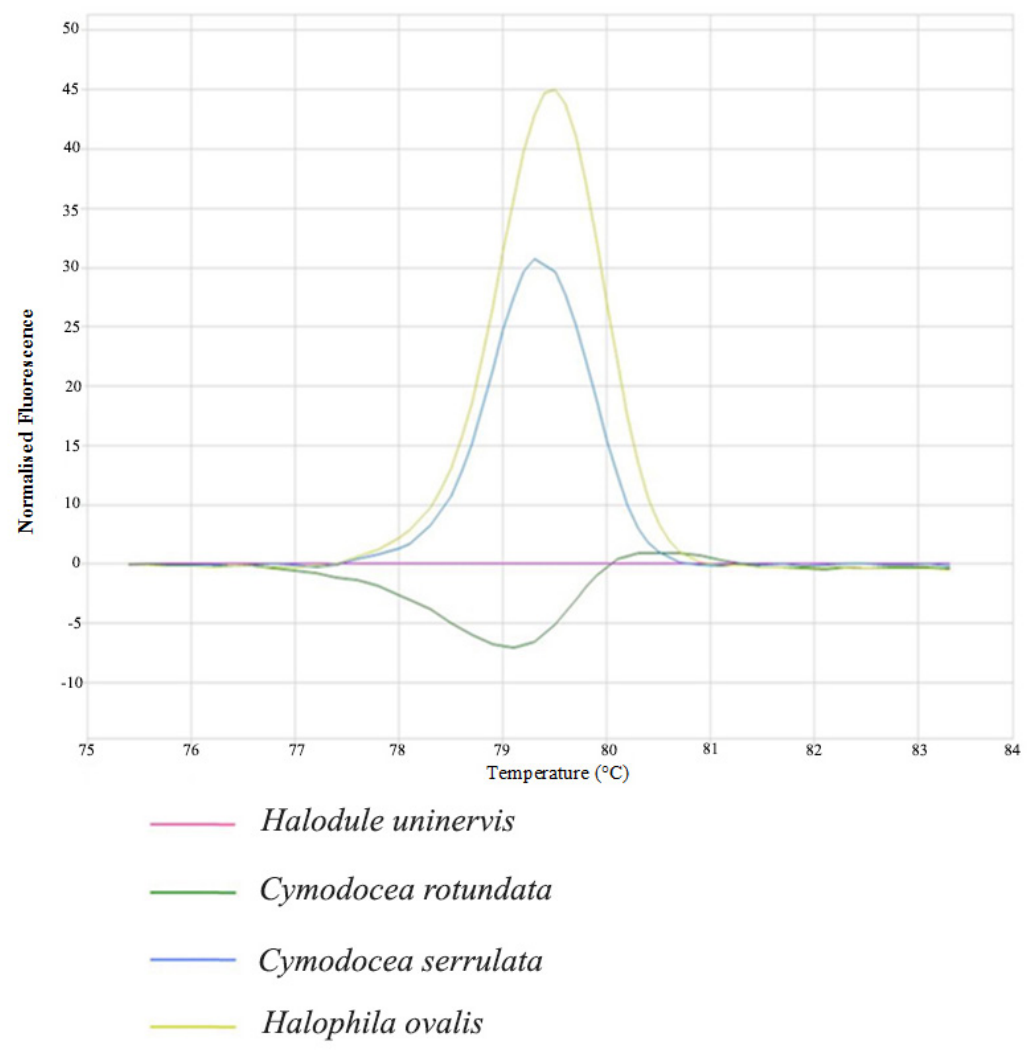

Figure 3. Normalized HRM curves for the amplicons from the four seagrass species based on HRM analysis with specific and rpoC primers.

\section{CONCLUSIONS}

The BAR-HRM analysis using the designed $r b c \mathrm{~L}$ and $r p o \mathrm{C}$ primer sets demonstrated that it is a useful, simple, fast, and economical approach to discriminate between seagrass species. With continued improvements, BAR-HRM may be of great importance not only for seagrass plant taxonomy, but for related fields as well.

\section{ACKNOWLEDGMENTS}

Research supported by the Chiang Mai University under Grant CMU new researcher grant. We also thank Mr. Supasit Boonphienphol (Phuket Marine Biological Centre) for providing the samples analyzed. 


\section{REFERENCES}

Bastian M, Heymann S and Jacomy M (2009). Gephi: an open source software for exploring and manipulating networks. In: International AAAI Conference on Weblogs and Social Media. Computer program.

CBOL Plant Working Group, Hollingsworth PM, Forrest LL, Spouge JL, et al. (2009). A DNA barcode for land plants. Proc. Natl. Acad. Sci. U.S.A. 106: 12794-12797

Den Hartog C and Kuo J (2006). Taxonomy and biogeography of seagrasses. In: Seagrasses: Biology, Ecology and Conservation. (Larkum AWD, Orth, RJ and Duarte CM, eds.). Springer, New York, 1-23.

Faria MA, Magalhães A, Nunes ME and Oliveira MBPP (2013). High resolution melting of $t r n \mathrm{~L}$ amplicons in fruit juices authentication. Food Control. 33: 136-141.

Fazekas AJ, Burgess KS, Kesanakurti PR, Graham SW, et al. (2008). Multiple multilocus DNA barcodes from the plastid genome discriminate plant species equally well. PLoS One 3: e2802.

Ganopoulos I, Madesis P, Darzentas N, Argiriou A, et al. (2012). Barcode High Resolution Melting (Bar-HRM) analysis for detection and quantification of PDO "Fava Santorinis" (Lathyrus clymenum) adulterants. Food Chem. 133: 505-512.

Hine EM, Adulyanukos K and Duffu DA (2005). Dugong (Dugong dugon) abundance along the Andaman coast of Thailand. Mar. Mammal Sci. 21: 536-549.

Hollingsworth PM, Forrest LL, Spouge JL, Hajibabaei M, et al. (2009). A DNA barcode for land plants. Proc. Natl. Acad. Sci. U.S.A. 106: 12794-12797.

Kress WJ and Erickson DL (2007). A two-locus global DNA barcode for land plants: the coding $r b c$ L gene complements the non-coding $t r n \mathrm{H}-p s b \mathrm{~A}$ spacer region. PLoS One 2: e508.

Kress WJ and Erickson DL (2008). DNA barcodes: genes, genomics, and bioinformatics. Proc. Natl. Acad. Sci. U.S.A. 105: 2761-2762.

Kress WJ, Wurdack KJ, Zimmer EA, Weigt LA, et al. (2005). Use of DNA barcodes to identify flowering plants. Proc. Natl. Acad. Sci. U.S.A. 102: 8369-8374.

Lahaye R, Van der Bank M, Bogarin D, Warner J, et al. (2008). DNA barcoding the floras of biodiversity hotspots. Proc. Natl. Acad. Sci. U.S.A. 105: 2923-2928.

Lucas C, Thangaradjou T and Papenbrock J (2012). Development of a DNA barcoding system for seagrasses: successful but not simple. PLoS One 7: e29987.

Newmaster SG, Fazekas AJ and Ragupathy S (2006). DNA barcoding in the land plants: evaluation of $r b c L$ in a multigene tiered approach. Can. J. Bot. 84: 335-341.

Newmaster SG, Fazekas AJ, Steeves RA and Janovec J (2008). Testing candidate plant barcode regions in the Myristicaceae. Mol. Ecol. Res. 8: 480-490.

Orth RJ (2006). A global crisis for seagrass ecosystems. BioScience. 56: 987-996.

Poovachiranon S (1988). Preliminary observation on communities of seagrass beds in Phangnga Bay, Andaman Sea. Proceedings of Seminar on Fisheries. Department of Fisheries, Bangkok, 404-414.

Poovachinranon S and Chansang H (1994). Community structure and biomass of seagrass beds in the Andaman Sea. I. Mangrove-associated seagrass beds. Phuket Mar. Biol. Cent. Res. Bull. 59: 53-56.

Poovachiranon S and Adulyanukosol K (1999). Seagrass community and marine algae in Thailand. Proceedings of $1^{\text {st }}$ KoreaThailand Joint Workshop on Comparison of Coastal Environment, Korea-Thailand. Seoul, 84-96.

Poovachiranon S, Adulyanukosol K, Saelim P, Charoenpornwattana A, et al. (2006). Seagrasses in Thai Waters. Phuket Mar. Biol. Cent. Res. Bull. 138: 24-27

Reusch TBH, Stam WT and Olsen JH (1999). Microsatellite loci in eelgrass Zostera marina reveal marked polymorphism within and among populations. Mol. Ecol. 8: 317-322.

Sakayaroj J, Preedanon S, Supaphon O, Jones EBG, et al. (2010). Phylogenetic diversity of endophyte assemblages associated with the tropical seagrass Enhalus acoroides in Thailand. Fungal Divers. 42: 27-45.

Sakaridis I, Ganopoulos I, Argiriou A and Tsaftaris A (2013). A fast and accurate method for controlling the correct labeling of products containing buffalo meat using High Resolution Melting (HRM) analysis. Meat Sci. 94: 84-88.

Short FT, Carruthers T, Dennison W and Waycott M (2007). Global seagrass distribution and diversity: A bioregional model. J. Exp. Mar. Biol. Ecol. 350: 3-20.

Tamura K, Peterson D, Peterson N, Stecher G, et al. (2011). MEGA5: Molecular evolutionary genetics analysis using maximum likelihood, evolutionary distance, and maximum parsimony methods. Mol. Biol. Evol. 28: 2731-2739.

Terrados J, Borum J, Duarte CM, Fortes MD, et al. (1999). Nutrient and mass allocation of South-east Asian seagrasses. Aquat. Bot. 63: 203-217.

Wittwer CT, Reed GH, Gundry CN, Vandersteen JG, et al. (2003). High resolution genotyping by amplicon melting analysis using LCGreen. Clin Chem. 49: 853-860. 